\title{
Parliament's Role Following Declarations of Incompatibility under the Human Rights Act
}

\author{
Jeff King *
}

$\mathrm{T}$

HE Human Rights Act 1998 (HRA) has been called 'the cornerstone of the

New Constitution' 1 and even 'one of the most important pieces of

legislation to be enacted in the twentieth century'. ${ }^{2}$ As is well known, however, UK courts have no power to strike down a statute on account of it violating the European Convention on Human Rights (hereinafter the 'Convention'), which the HRA effectively makes the UK's bill of rights. Rather, if a UK court cannot 'so far as possible' read a UK statute consistently with Convention rights under section 3, they repair to section 4(2): 'If the court is satisfied that the provision is incompatible with a Convention right, it may make a declaration of that incompatibility.' Furthermore, section 4(6) of the HRA confirms that any such declaration 'does not affect the validity, continuing operation or enforcement of the provision in respect of which it is given; and ... is not binding on the parties to the proceedings in which it is made'.

Thus far, UK courts have issued 20 such section 4 declarations that were not overturned on appeal, ${ }^{3}$ and the purpose of this chapter is to explore the practice of the

\footnotetext{
* The author would like to thank Alison Young, Murray Hunt, Paul Yowell, Nicholas Bamforth, Aileen Kavanagh, Nick Barber, James Melton, Aileen McHarg, Hayley Hooper, Cheryl Thomas and Gordon Anthony for helpful substantive guidance at various points. For research assistance, I would like to thank Cosimo Montagu, Nick Bamber, Stefan Theil, Quentin Montpetit and William Achorn. I thank in particular the UCL Faculty of Laws and the UCL Constitution Unit for making extensive resources available to me, both human and financial. I wish to record a particularly outstanding debt to Nick Bamber and Cosimo Montagu. Their extensive work in collecting judicial data and finding and organising Hansard was critical to the project and was conducted with the very highest degree of academic excellence.

${ }^{1}$ V Bogdanor, The New British Constitution (Oxford, Hart Publishing, 2009) ch 3.

2 J Stanton, 'Review: Parliamentary Sovereignty and the Human Rights Act-By Alison L Young' (2010) 30 Legal Studies 689, 689.

${ }^{3}$ Note that hereinafter, these judicial decisions will be referred to by party name only and not with constant citation in the text. As of June 2014, the cases include (with numbering added for convenience): (1) $R(H) v$ Mental Health Review Tribunal for the North and East of London Region, and the Secretary of State for Health [2001] EWCA Civ 415; (2) McR's Application for Judicial Review [2002] NIQB 58; (3) International Transport Roth GmBH v SSHD [2002] EWCA Civ 158; (4) $R$ (on the application of Anderson) $v$ SSHD [2002] UKHL 46; (5) $R(D) v$ SSHD [2002] EWHC 2805 (Admin); (6) Blood and Tarbuck v SS for Health (3 March 2003, unreported); (7) Bellinger v Bellinger [2003] UKHL 21; (8) $R(M) v$ Secretary of State for Health [2003] EWHC 1094; (9) $R$ (Wilkinson) $v$ Inland Revenue Commissioners [2003] EWCA Civ 814; (10) R (Hooper) v SSWP [2003] EWCA Civ
} 
UK courts under this system, how that compares with some experiences abroad, how Parliament has responded to such declarations, and what it all says about the nature and constitutional role of the remedial scheme for the judicial review of legislation set out in the HRA. More particularly, I will shed preliminary light on the answers to the following set of questions:

- What form have parliamentary and governmental responses to section 4 declarations taken, how promptly and what kind of policies were enacted in response?

- Does the HRA promote or hinder democratic deliberation about rights in Parliament?

- Is there an emerging constitutional convention that the Government and Parliament ${ }^{4}$ are constitutionally obligated to respond to section 4 declarations by amending the offending legislation?

The preliminary answers to such questions do not all fit into a simple conceptual scheme bearing a headline message. The evidence is mixed. We must also be mindful, furthermore, of the methodological issue that such legal remedies have only been available for 14 years at the time of writing (10 of them under the Labour Party that enacted the HRA). On the other hand, this brief period enables a more or less exhaustive examination of the record in Parliament. The findings presented here are

875; however, see [2005] UKHL 29; (11) $A$ and others; $X$ and others $v$ SSHD [2004] UKHL 56; (12) $R$ (Morris) $v$ Westminster CC and the First Secretary of State [2005] EWCA Civ 1184; (13) $R$ (Gabaj) $v$ First Secretary of State (unreported); (15) R (Clift) v SSHD [2006] UKHL 54; (16) Smith v Scott [2007] CSIH 9 (Scotland); (17) $R$ (Baiai) v SSHD [2008] UKHL 53; (18) $R$ (Thompson) v SSHD [2010] UKSC 17; (19) $R$ (Royal College of Nursing) v SSHD [2010] EWHC 2761 (Admin); (20) R(T) v Chief Constable of Greater Manchester [2014] UKHL 35. This mirrors the findings in the Ministry of Justice's Responding to Human Rights Judgments (2012, Cm 8432) Annex A, apart from the last, which was decided in June 2014. Note: Hooper is inaccurately represented in the official list. The decision reported at [2003] EWCA Civ 875 was final, but did not involve the issuance of a declaration of incompatibility. The correct citation for the Hooper appeal case addressing the substantive issue was [2003] EWCA 813. However, this case was overruled in [2005] UKHL 29. The House of Lords acknowledged the incompatibility and confirmed the analysis of Moses $\mathrm{J}$ at first instance (which issued a declaration of incompatibility), but felt that due to the repeal of the statute, a new declaration was no longer needed (see [52], [79]). Despite the tortuous path of litigation and unclear message, I have elected to keep Hooper on the list.

${ }^{4}$ Although private members are entitled to put forward bills in Parliament, it remains the case that 'private members' bills which arouse any substantial degree of opposition are unlikely to pass into law' (M Jack (ed), Erskine May: Parliamentary Practice (24th edn, London, LexisNexis, 2011) 526) and hence those that succeed typically have cross-party support. In practice, therefore, the role of Parliament is dictated by the choices of the Government on how to proceed in remedying the incompatibility. Even so, the Human Fertilisation and Embryology (Deceased Fathers) Act 2003 is one example of a private member's bill remedying a section 4 declaration of incompatibility. The Bill passed without division in both Houses of Parliament: HC Deb 13 June 2003, vol 406, col 996; HL Deb 18 September 2003, vol 652, col 1057. 
based on scrutiny of all parliamentary debates on every remedial response to a section 4 declaration, on the floor of each House, in Committees, at Report and 'Ping Pong' (consideration of amendments) stages, and in consideration of the relevant scrutiny reports of the Joint Committee on Human Rights (JCHR) on each remedial response. ${ }^{5}$ Thus, while the period is too brief for sweeping generalisations about the definitive constitutional role of section 4 declarations, the completeness of the record allows some interesting insights to emerge. The general picture is of a remedial regime that differs in important ways from some other weak and strong form systems of constitutional judicial review. The parliamentary record displays an attitude that has been predominantly accepting of and collaborative with the courts' role, though also minimalist in some responses and on the whole manifesting delays by the Government that have no principled defence. Lastly, it appears that there is, indeed, evidence of an emerging constitutional convention of response by the Government and Parliament to section 4 declarations of incompatibility.

\section{The Landscape of Section 4 Declarations of Incompatibility}

\section{A. The Types of Legislative and Government Response}

The Government may respond to a declaration of incompatibility in various ways. First, it legally can choose to do nothing at all. Where this has occurred, however, it was because Parliament had already amended the offending legislation prior to the declaration (as noted in Figure 8.1 below). On the other hand, despite some lengthy delays and the possible exception of prisoner voting (as discussed further below), there has been no case to date where the Government or Parliament affirmatively chose not to remedy incompatible legislation. Second, the Government can ask Parliament to repeal the offending provision by way of an Act of Parliament. In doing so, it can either introduce an act among whose central purposes is the intention to address the incompatibility (which I will call 'whole act responses') or it can add a provision to an existing bill that may be related to the issue, but that primarily

\footnotetext{
${ }^{5}$ I have not examined any remedial responses to findings of rights violations by the European Court of Human Rights.
} 
concerns other matters (which I will call 'tacking responses'). Third and finally, the Government can amend and replace the offending provision by way of a remedial order under section 10 of the HRA. This section empowers a minister to use subordinate legislation (an executive order) to amend the act to remove the incompatibility. As specified in Schedule 2 to the HRA, the remedial order must be laid before Parliament for an affirmative resolution, either before it comes into force or, in urgent cases where it is necessary to give it immediate effect, by way of affirmative resolution after it has come into force. The remedial orders are also subject to scrutiny by the JCHR, which has also given guidance in relation to when the use of remedial orders is appropriate. ${ }^{6}$ Indeed, the JCHR's role in the parliamentary process is absolutely crucial, though it is explained in detail elsewhere in this volume. The broader landscape of the response to declarations of incompatibility under the HRA is set out in Figure 8.1.

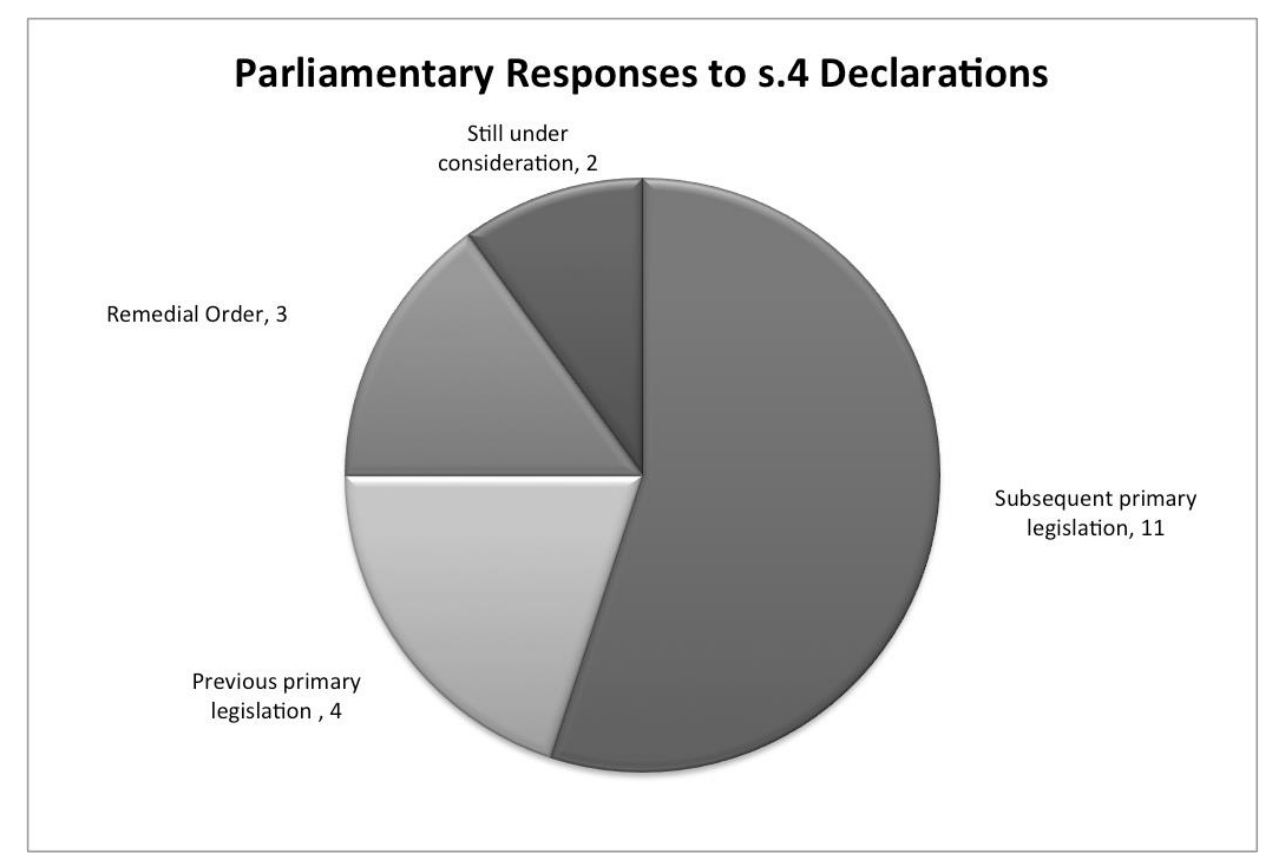

Figure 8.1 Parliamentary responses to section 4 declarations ${ }^{7}$

\footnotetext{
${ }^{6}$ Joint Committee on Human Rights, Making of Remedial Orders (2001-02, HL 58, HC 473); see also the Committee's Enhancing Parliament's Role in Relation to Human Rights Judgments (2009-10, HL 85, HC 455) [22]-[24]. See also Guidance to Departments at back of this Report.

${ }^{7}$ Please consult the methodological appendix at the end of this chapter for information on all other figures in this chapter.
} 
The chart in Figure 8.1 discloses an unmistakable preference for acting through the ordinary legislative procedure. This may explain some of the delays I will shortly detail. I return to this issue below.

\section{B. Promptness of Response}

One of the most important differences between the HRA and some foreign systems is the fact that the Government is capable of delaying its response to a section 4 declaration by a considerable amount of time. Only political pressure-usually from the JCHR and civil society - can accelerate the response. As Figure 8.2 shows, the delay between the court judgment and the remedial provision coming into force is fairly substantial.

\section{[Insert Figure 2 around here].}

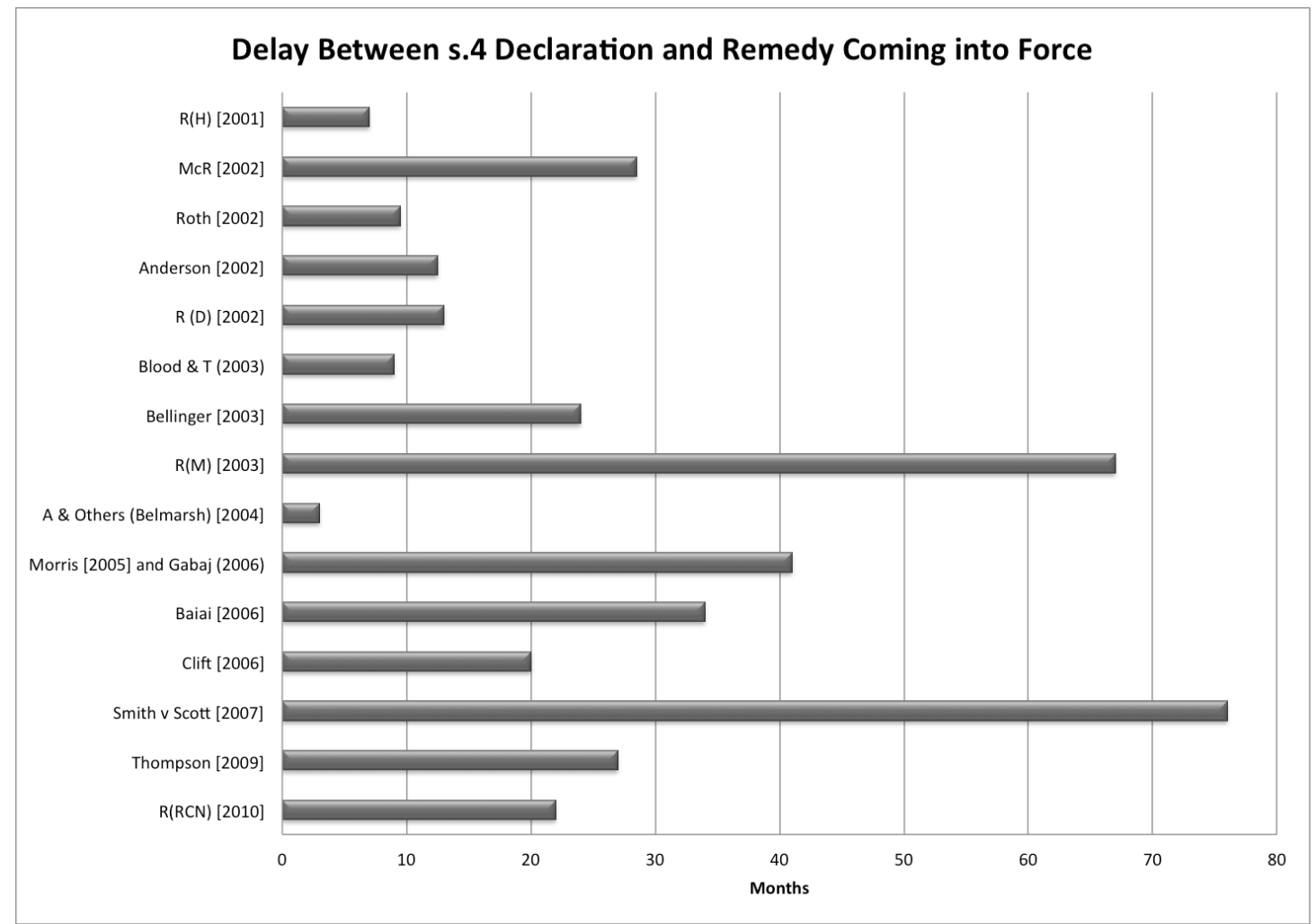

Figure 8.2 The delay between the section 4 declaration and the remedy coming into force

The two outliers in Figure 8.2 are the $R(M)$ and Smith $v$ Scott cases. The former case involved a defect in the mental health regime, which for the relevant 
mental health patients automatically appointed as guardian the 'nearest relative' without the possibility of the patient applying for variation. In M's case, the patient's 'nearest relative' was her adoptive father, whom she accused of having sexually abused her. The case thus involved a classic legislative oversight. The incompatibility was conceded in the $M$ case, as shown through the exhaustive analysis by Alison Young of the passage of the remedial legislation through Parliament, which demonstrates that the process was exemplary of dialogue working rather than of stubborn foot-dragging. ${ }^{8}$ Whether the delay was justifiable is another story. The Smith $v$ Scott case applied the Strasbourg Court's Hirst decision, ${ }^{9}$ which found a blanket ban preventing convicted prisoners from voting to be a disproportionate interference with their (constructive) right to vote under Article 3 of the First Protocol to the Convention. The Government has published a draft bill in response, which presents three mutually exclusive options: (1) a voting ban on prisoners sentenced to four years or more; (2) one for those sentenced to more than six months; and (3) maintenance of the current blanket ban in outright defiance of the Strasbourg judgment. ${ }^{10}$ The draft bill has now been scrutinised by a joint committee. ${ }^{11}$ The Government has sent mixed messages about its plans for the draft bill. On the one hand, the Prime Minister declared unequivocally in response to a parliamentary question that 'prisoners are not getting the vote under this government'. ${ }^{12}$ On the other hand, there is a repeated affirmation that the Government's policy is to comply with its international obligations, including the decision of the Strasbourg Court, but that the ultimate decision rests with Parliament. ${ }^{13}$ The constitutional significance of this delay for the role of the HRA is further complicated by the fact that UK courts flatly denied to

\footnotetext{
${ }^{8}$ AL Young, 'Is Dialogue Working under the Human Rights Act 1998?' [2011] Public Law 773, 78384.

${ }^{9}$ Hirst v UK (No 2) [2005] ECHR 681.

${ }^{10}$ I White, Prisoners' Voting Rights (SN/PC/01764) (London, Parliament and Constitution Centre, House of Commons Library, 15 May 2013).

${ }^{11}$ See Report of the Joint Committee on the Draft Voting Eligibility (Prisoners) Bill, Session 2013-14, HL Paper 103/HC 924 (18 December 2013).

${ }^{12}$ HC Deb 24 October 2012, vol 551, col 923.

${ }^{13}$ HC Deb 22 November 2012, vol 553, col 745 (Chris Grayling MP): 'The Prime Minister has made clear, on the record, his personal views on this subject, and I have done the same. Those views have not changed. However, the Government are under an international law obligation to implement the Court judgment. As Lord Chancellor, as well as Secretary of State for Justice, I take my obligation to uphold the rule of law seriously. Equally, it remains the case that Parliament is sovereign, and the Human Rights Act 1998 explicitly recognises that fact.' The Ministry of Justice's explanatory memorandum for the draft Bill (Cm 8499) makes the same point at [2].
} 
award a declaration of incompatibility in the pre-Strasbourg UK challenge under the HRA, ${ }^{14}$ and the matter is generally viewed by parliamentarians as a contest between the UK and Strasbourg, instead of between the UK courts and the UK Parliament and Government.

Quite apart from these cases, the delays are nonetheless significant. This is true even if we compare the UK with jurisdictions where courts have a practice of suspending the effect of their declarations of unconstitutionality, a remedy which allows the unconstitutional law to remain effective for a particular period of time pending an appropriate legislative response. Figure 8.3 compares the rate of delay with that observed in Canada, France and Germany.

\section{[Insert Figure 3 around here].}

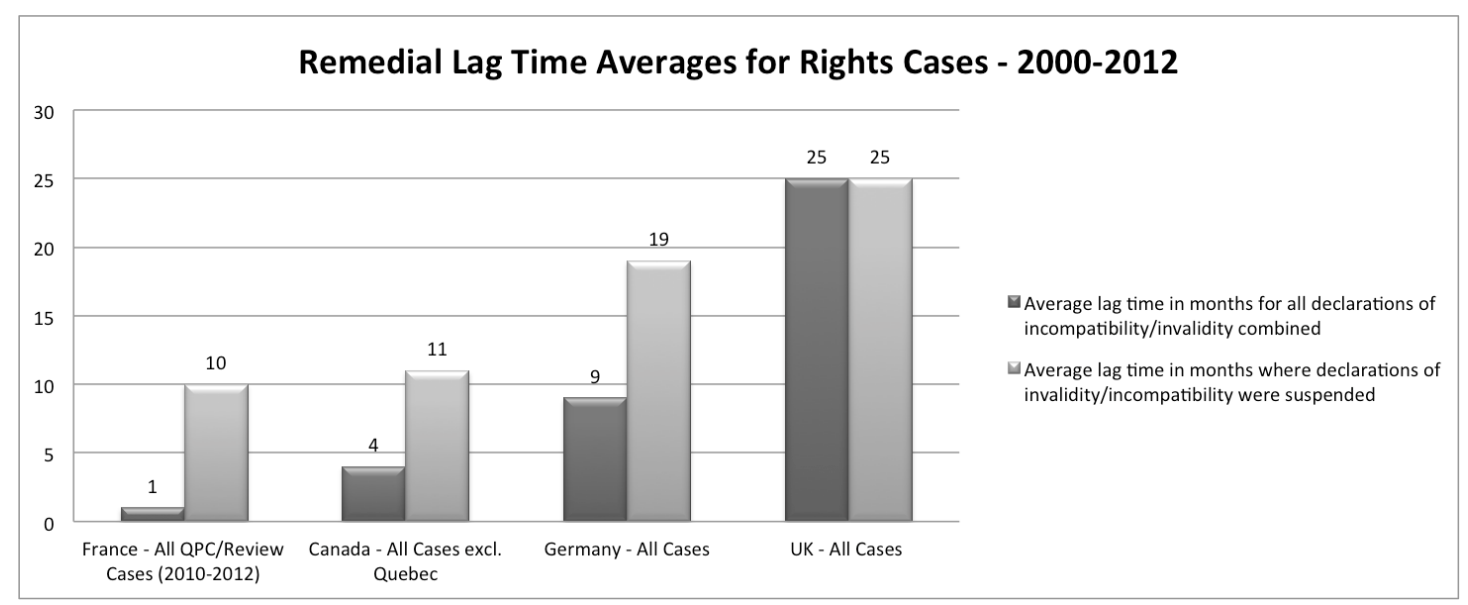

Figure 8.3 Remedial lag time averages for rights cases: 2000-12

Thus, even where the constitutional remedy of delaying or suspending the operation of the declaration of unconstitutionality exists in other systems, the overall period of delay under the HRA is significantly higher. There may or may not be aspects of the legislative process that are partly responsible for this delay. Yet it is reasonable to conclude that a major cause of this difference is the binding effect of the period stipulated by the foreign courts and, more importantly, because suspended

\footnotetext{
${ }^{14} R$ (on the application of Pearson and Feal-Martinez) v SSHD; Hirst v HM Attorney General [2001] EWHC Admin 239; HC Deb 10 February 2011, vol 523, cols 493-586.
} 
declarations only account for a subset of overall cases. At first it appears that once we exclude the $R(M)$ (mental health) and Smith $v$ Scott (prisoner voting) cases, the differences between the UK, Canada and Germany are not particularly strong. If we exclude them, for instance, the average lag time for the UK is approximately 17 rather than 25 months. However, if we look at the figures for delay regarding all declarations of unconstitutionality in the Canadian and German courts rather than the subset of those where the declaration was suspended, we see that the overall average delay is still much greater in the UK. Furthermore, if we exclude only $R(M)$ and continue to include the prisoner voting case, which is highly pertinent to the enquiry here and arguably not a case of good faith dialogic engagement, the average delay remains 22 months. On any accounting, therefore, the delays are substantially greater in the UK.

\section{General Impact on the Legislative Process}

We can consider the question of impact by looking at the number of judgments and extent of the impact of such judgments. As to the first, data compiled for this study shows that the number of statutes declared unconstitutional or subject to declarations of incompatibility is rather low in international comparison with Canada, France or Germany.

[Insert Figure 4 around here - comparative strike down rates].

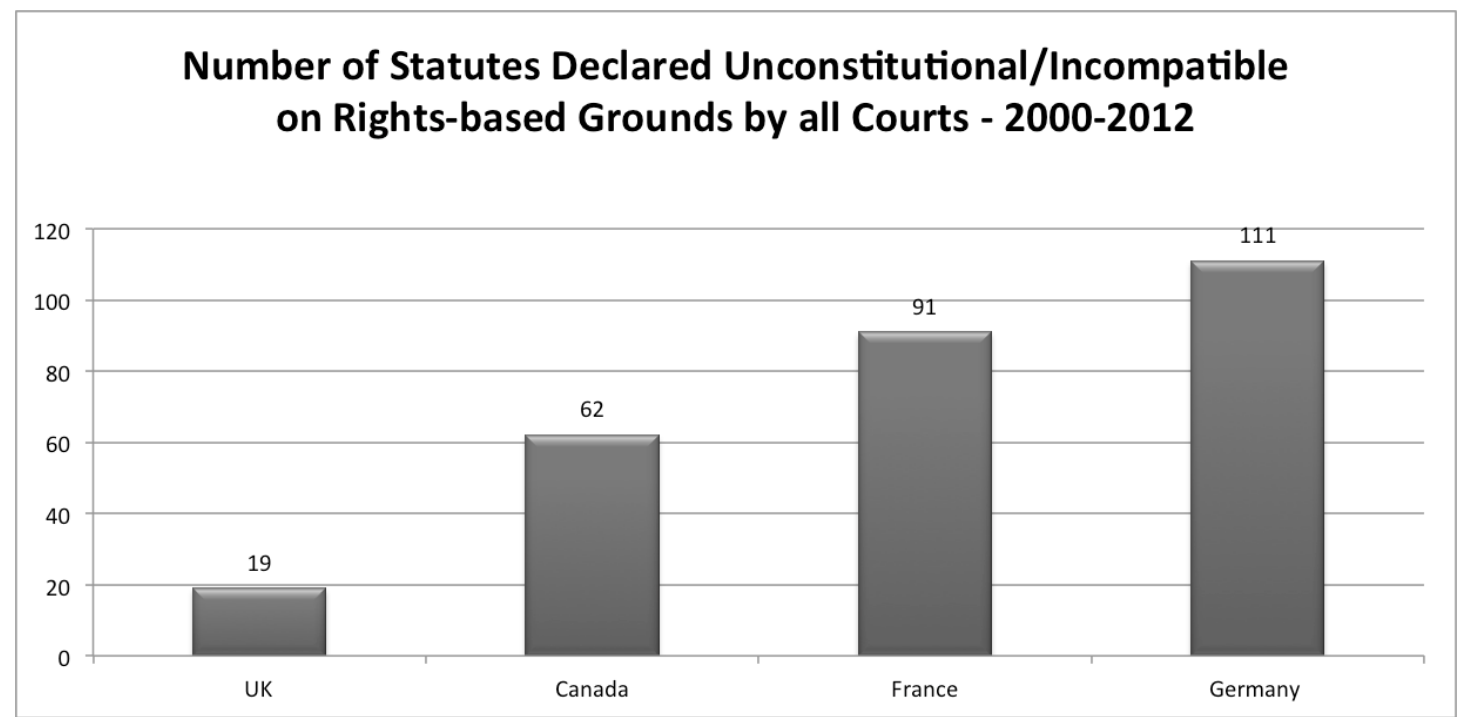


Figure 8.4 Number of statures declared unconstitutional/incompatible on rightsbased grounds by all courts 2000-12

Admittedly, the number of declarations of incompatibility is only one (albeit important) aspect of the judiciary's impact on legislation under the HRA. Some writers treat the particularly muscular power of legislative interpretation available under section 3 of the HRA (allowing reading in and reading down) as a form of judicial supremacy tantamount to a strike down power. ${ }^{15}$ Although to date no systematic analysis of how often section 3(1) is used in this fashion has been undertaken (nor to my knowledge of its analogues in the Canadian and German systems), ${ }^{16}$ it appears to be relatively infrequent in the UK. At any rate, the low number of declarations of incompatibility under the HRA means that the law-makers' business is disrupted somewhat infrequently by rights review under the HRA. This may help explain why they have what Sathanapally calls a 'low profile' ${ }^{17}$ in Parliament.

Another potential reason for the low profile relates to the extent of impact generated by the particular decisions. Impact can be judged along a number of lines. ${ }^{18}$ It can have direct and indirect effects. It may involve symbolic or expressive impact (such as non-pecuniary satisfaction, strengthening constitutional values, exposing unlawful behavior in the media or by eroding public support for human rights values by providing opportunities for media spin). It may involve the provision or loss of certain benefits, services or other rights for individuals. It may consist of new allocative costs and other disruptions to administration or result in a response that eliminates a discretion that was previously used to benefit a number of persons. Alternatively, it may be a form of political backlash in which opposition to the judgment sets back the overall enjoyment of the right even further. ${ }^{19}$ On the whole,

15 S Gardbaum, The New Commonwealth Model of Constitutionalism (Cambridge, Cambridge University Press, 2013) 171, 185.

${ }^{16}$ Both of which are explained in the Methodological Appendix at the end of this chapter.

${ }^{17}$ A Sathanapally, Beyond Disagreement: Open Remedies in Human Rights Adjudication (Oxford, Oxford University Press, 2012) 138-39.

${ }^{18}$ See S Halliday and M Hertogh (eds), Judicial Review and Bureaucratic Impact (Cambridge, Cambridge University Press, 2004).

${ }^{19} \mathrm{I}$ have explored a number of these areas and the phenomenon of backlash in Judging Social Rights (Cambridge, Cambridge University Press, 2012) 63-85. 
impact concerns not only the number of persons affected by the decision, but also the nature of the impact on particular individuals.

These are difficult dimensions in the study law and politics, and they caution against making sweeping generalisations about impact in particular regimes. Subject to that caveat, it is important to have a look at the most immediate political impact judged by the policies enacted in response to the various judgments, responses which have been endorsed as compliant with the judgments by the independent JCHR. Table 8.1 sets out a representative sample of such responses. ${ }^{20}$ It shows that the immediate discernible impact of the HRA, while in my view very worthwhile, has also been relatively modest in respect of the number of people affected and the extent of intrusion into controversial legislative territory. A number of such cases concern procedural rights or matters regarded as legislative oversight, and relatively few extended expensive or controversial benefits. Even the most significant cases tended to affect thousands of persons (at least in the initial years following the judgment), contrary to what is often the case in America and Germany.

\footnotetext{
${ }^{20}$ The sample contains most and is definitely representative. I have omitted cases where the legislation was in place before the declaration. I also omitted the much-debated impact of the Belmarsh case, which led to the Prevention of Terrorism Act 2005 and with it the new control order regime. In numbers, between 2005 and 2011, there were a total of 52 control orders issued, all related to suspected Islamic terrorists, primarily in later years against UK nationals (not permitted under the pre-Prevention of Terrorism Act regime). See D Anderson, Control Orders in 2011: Final Report of the Independent Reviewer on the Prevention of Terrorism Act 2005 (London, The Stationery Office, 2012). As a matter of sheer numbers, then, the impact was modest and perhaps even facilitated the expansion of executive detention without charge through a rushed parliamentary process: see the text accompanying nn 49-55 below. However, since the case and its successors have concerned deprivations of liberty without ordinary due process, it took on a symbolic importance among writers that is far greater than these numbers suggest.
} 
Table 8.1 Impact of section 4 declarations: a representative sample

\begin{tabular}{lll}
\hline Impact & \multicolumn{1}{c}{ Case } & \multicolumn{1}{c}{ Outcome } \\
\hline Minimal & Anderson & $\begin{array}{l}\text { Replacement of Home Secretary's discretion to increase duration of term of } \\
\text { imprisonment (the tariff) served without parole with a legislative scheme of } \\
\text { proposed 'starting point' minimum sentences, dubbed 'Blunkett's revenge' } \\
\text { by a peer. }\end{array}$ \\
& $\begin{array}{l}\text { Blood and } \\
\text { Tarbuck }\end{array}$ & $\begin{array}{l}\text { Amendment to scheme to allow deceased father's name to be added to a } \\
\text { child's birth certificate. }\end{array}$
\end{tabular}

Morris $\begin{aligned} & \text { Challenged scheme for fighting 'benefits tourism' required local authorities } \\ & \text { assessing priority need for homelessness assistance to disregard non- } \\ & \text { nationals who required leave to remain in the country. New scheme } \\ & \text { extended rights to British, EU and certain Commonwealth citizens to be } \\ & \text { given an offer of accommodation (no more) in the private rented sector for } \\ & \text { a duration of one year. }{ }^{22}\end{aligned}$
$\begin{aligned} & \text { Royal } \\ & \text { College of } \\ & \text { Nurses }\end{aligned}$
$\begin{aligned} & \text { Challenged scheme allowing persons barred from working with children or } \\ & \text { representations only after the barring decision. Revised scheme permits } \\ & \text { representations before the barring decision. }{ }^{23}\end{aligned}$

${ }^{21}$ HL Deb 16 June 2003, vol 649, col 588 (Lord Ackner); see also cols 575-77 (Lord Woolf). The new sentencing guidelines in effect provided a legislative framework of sentencing that not only replaced the guidelines developed by the judges earlier, but also departed substantially from them in substance. The case may therefore be considered an instance of political backlash and in that respect its impact, seen as cutting against the spirit of the judgment to which it responded, may have been more than moderate.

${ }^{22}$ HC Deb 21 July 2008, vol 673, cols 610-13.

${ }^{23}$ Protection of Freedoms Act 2012, s 67. 


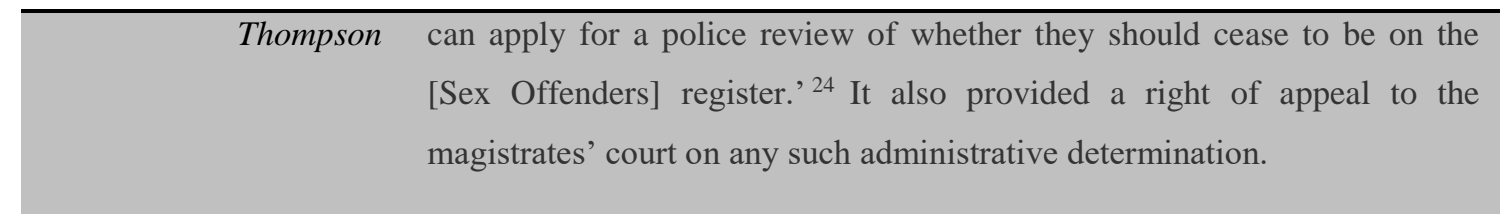

Bellinger $\begin{aligned} & \text { The Gender Recognition Act } 2005 \text { clarified the legal consequences of } \\ & \text { gender recognition and established the Gender Recognition Tribunal, } \\ & \text { which by } 2012 \text { had issued 3,108 full Gender Recognition Certificates. }\end{aligned}$
Significant $\begin{aligned} & \text { Roth } \\ & \text { Replacement of mandatory heavy penalty scheme applicable to hauliers } \\ & \text { carrying clandestine entrants to the UK with a new executive power to } \\ & \text { reduce fines coupled with new rights of appeal. } \\ & \text { Baiai } \\ & \text { Abolition of a discriminatory scheme that, in an effort to prevent 'sham } \\ & \text { marriages'. prohibited people subject to immigration control from marrying } \\ & \text { without authorisation, except in a Church of England (CoE) religious } \\ & \text { ceremony. The Government did not level down, but extended to all such } \\ & \text { persons the rights enjoyed by those marrying in a CoE religious ceremony. }\end{aligned}$

\section{Do Declarations of Incompatibility Promote Greater Democratic Deliberation?}

There has been a significant amount written about the idea of constitutional judicial review as 'democratic dialogue' between courts and legislatures, notably in Canada, ${ }^{26}$

\footnotetext{
${ }^{24}$ HL Deb 5 July 2012, vol 738, cols 875, 876 (Baronness Stowell of Beeston, introducing the order in the Lords). See Joint Committee on Human Rights, Draft Sexual Offences Act 2003 (Remedial) Order 2012 (Second Report) (2012-13, HL 8, HC 166) [14]-[17] (discussing the dialogue between the JCHR which convinced the Government to add the appeal to the magistrates' court, but not to the High Court or Crown Court. The case serves as a good example of the benefits of intra-parliamentary dialogue on rights review).

${ }^{25}$ Ministry of Justice, Statistics Bulletin: Gender Recognition Statistics: October to December 2012 (4 April 2012).

${ }^{26}$ See (2007) 45 Osgoode Hall Law Journal 1 for an issue dedicated entirely to the metaphor of dialogue and reply by the principal authors of the idea in Canadian law to their critics. Kent Roach has expounded and defended the idea in a range of publications: see, eg, 'Dialogic Judicial Review and its Critics' (2004) 23 Supreme Court Law Review 49 and 'Sharpening the Dialogue Debate: The Next Decade of Scholarship' [2007] 45 Osgoode Hall Law Journal 169. For a fresh perspective, see R Dixon, 'The Supreme Court of Canada, Charter Dialogue, and Deference' [2009] 47 Osgoode Hall
} 
in respect of the HRA, ${ }^{27}$ and in at times unfairly neglected earlier work on this theme by Barry Friedman in the US. ${ }^{28}$ The basic idea as outlined in the seminal article by Hogg and Bushell (now Thornton) is as follows: 'Where a judicial decision is open to legislative reversal, modification, or avoidance, then it is meaningful to regard the relationship between the Court and the competent legislative body as a dialogue. ${ }^{29}$ The authors argue that where dialogue occurs, 'any concern about the legitimacy of judicial review is greatly diminished' ${ }^{30}$ However, they later appear to back down from this normative claim. ${ }^{31}$

It is important not to be distracted by the metaphor of dialogue and the debates about its accuracy and significance. ${ }^{32}$ The more focused question is whether there is something about the scheme in the HRA that promotes improved democratic deliberation, ${ }^{33}$ not whether it leads to exchanges that are iterative in the egalitarian sense implied by the dialogue metaphor. So some pertinent questions include the following: are Members of Parliament welcoming of judicial decisions under the HRA thus far or do they feel dominated by them? Do they exercise their own normative capacities when scrutinising remedial legislation or do they merely ratify what the judges say? Are they considering issues that may have been neglected or are they being forced to backtrack grudgingly from earlier legislative commitments?

Law Journal 235 (exploring in particular the role of courts in 'second-look' cases where legislation enacted in response to previous judgments is challenged again).

${ }^{27}$ T Hickman, 'Constitutional Dialogue, Constitutional Theories and the Human Rights Act 1998' [2005] Public Law 306; AL Young, Parliamentary Sovereignty and the Human Rights Act (Oxford, Hart Publishing, 2009) esp ch 5; AL Young, 'Deference, Dialogue and the Search for Legitimacy' (2010) 30 OJLS 815; Sathanapally (n 17).

${ }^{28}$ B Friedman, 'Dialogue and Judicial Review' (1993) 91 Michigan Law Review 577. At 653, for instance, he states: 'The Constitution is not interpreted by aloof judges imposing their will on the people. Rather, constitutional interpretation is an elaborate discussion between judges and the body politic.'

${ }^{29}$ PW Hogg and AA Bushell, 'The Charter Dialogue between Courts and Legislatures (or Perhaps the Charter of Rights isn't Such a Bad Thing after All)’ (1997) 35 Osgoode Hall Law Journal 75, 79.

30 ibid 80.

${ }^{31}$ PW Hogg, AAB Thornton and WK Wright, 'Charter Dialogue Revisited - or Much Ado about Metaphors' (2007) 45 Osgoode Hall Law Journal 1, 30: 'Dialogue theory does not provide a justification for judicial review.'

${ }^{32}$ For sceptical views about the relevance of the debate and metaphor, see A Kavanagh, Constitutional Review under the UK Human Rights Act (Cambridge, Cambridge University Press, 2009) (n 13) 408411; Gardbaum (n 15) 15-16 and ch 5.

${ }^{33}$ For the view that judicial review can play this role more generally, see S Fredman, Human Rights Transformed: Positive Rights and Positive Duties (Oxford, Oxford University Press, 2008). 
Two excellent studies have examined a few of these questions in some detail, though for reasons of space they cannot be reviewed fully here. ${ }^{34}$ In her important article, Alison Young examines whether dialogue is working under the HRA by looking at Hansard relating to a range of legislative responses for important select cases. ${ }^{35}$ Young both reviews the experience under the HRA and also presents an analytical framework detailing normative guidance for legal interpretation that will enhance democratic dialogue under the HRA. My concern here is with the former aspect. Young examines, in this respect, legislative debates that involved interpretation of the rights that extended well beyond the judicial interpretations, particularly in the cases of $R(M)$, Bellinger, Roth and Morris. ${ }^{36}$ She regards the debates surrounding $R(M)$ and Bellinger as showing extensive debates regarding the appropriate remedy, rather than definition of the right, and that Morris involved debates about both. Roth, by contrast, was an instance of where the legislature largely accepted the Court of Appeal's analysis and did not engage with the balancing exercise presented by the issue. Young concludes that judicial deference on questions of rights is preventing the proper functioning of democratic dialogue, because the judges have pre-empted discussion in Parliament by showing a priori deference in their judgments. The judges should rather avoid withholding their views, so that parliamentarians can take them well into account when devising their response. Sathanapally's book examines dialogue and deliberative democratic theory before exploring in detail the use of section 4 declarations and, in particular, illuminating case studies of the Bellinger and Belmarsh cases.

My own analysis examining all instances of Hansard (debates in the Commons and the Lords, inclusive of Committee, Report and Ping Pong stages), as well as relevant committee reports, is at present still underway. However, some pictures are emerging that complement and to some extent confirm and extend the analyses by Young and Sathanapally. As to the idea that the courts may be 'dominating' Parliament in some fashion, there is almost no evidence of this occurring if we are to

\footnotetext{
${ }^{34}$ The research in this chapter was completed shortly before the publication of Sathanapally's Beyond Disagreement (n 17), precluding any extensive consideration. I have nonetheless referred to parts of the analysis throughout this chapter.

35 Young (n 8).

36 ibid 782-91.
} 
take expressions of protest in Parliament as the key indicator. My analysis on this point accords with Sathanapally's, which finds that: 'The nature of interaction has generally been cooperative rather than conflictual.' 37 The case of Thompson (concerning the Sex Offenders Register), on which see section III below, was the exception to this general rule, but a bit of chafing does not undo the norm. The overall trend is one of simple workaday acceptance of the domestic court's judgment and the need to respond to it, sin ire et studio, or 'without passion or hatred' ${ }^{38}$ However, the superficial calm towards particular judgments should not necessarily be equated with political satisfaction with the substantive legal regime in place under the HRA. The acceptance of domestic court judgments may reflect a certain respect for judicial independence in British constitutional arrangements. The Conservative Party made a manifesto commitment prior to the 2010 election to repeal the HRA and replace it with a British bill of rights, though the commitment to repeal was abandoned in the Coalition Agreement (with the Liberal Democrats) that followed the election. ${ }^{39}$

One might, on the other hand, believe that the impact upon Parliament has been more insidious, with parliamentarians laconically accepting the policies implicitly mandated by the courts in section 4 declarations. On this point, there is clear evidence, in my view, that parliamentarians do view the role for courts as being one of interpreting the rights at first instance, and the role of Parliament to fashion the remedy as well as to undertake any balancing exercise not implicitly foreclosed by the judgment. As statements reproduced in section III below affirm, parliamentarians tend to view themselves as accepting and working with the judgments of the courts and not ordinarily being in a position to offer a contrary interpretation of the right once the court has ruled definitively on the issue. This is not necessarily insidious domination or subtle policy distortion, though it is arguably so. It may equally or perhaps better be regarded as evidence of parliamentarians accepting the constitutional division of

\footnotetext{
${ }^{37}$ Sathanapally (n 17) 224.

${ }^{38}$ The expression is borrowed from M Weber, Theory of Economic and Social Organization (trans AR Henderson and T Parsons, New York, Free Press, 1947) 340.

${ }^{39}$ An Invitation to Join the Government of Britain: The Conservative Manifesto 2010 (available at: www.conservatives.com) at 79 (proposing to replace the Act with a UK bill of rights that would 'encourage greater social responsibility'). The Coalition Agreement committed both parties to the investigation of the possibility of a bill of rights that would 'ensure' the Convention 'continues to be enshrined in British law'. See The Coalition: Our Programme for Government (London: Cabinet Office, May 2010) 11.
} 
responsibilities implied by the HRA and accession to the European Convention. As just observed, it is furthermore impossible to say that these latter grander constitutional questions have been in any way 'passive' in British politics since 2010. The UK's constitutional moment is as much right now as it was in 1998.

The phenomenon of 'passive acceptance' may, on the other hand, undercut any strong argument that under the HRA, Parliament plays an equal, revisory or final role in defining the rights themselves and assessing limitations to them, a point regarded as quite important by some writers. ${ }^{40}$ On the whole, however, there is perhaps too much emphasis on the point of 'normative finality' in discussions on this issue. Judges, under the HRA, hardly try to provide expansive or exhaustive definitions of the rights. Rather, they give case-by-case indications of how particular policies fail to comply with abstract rights, leaving much undecided both at the normative stage and in particular at the constructive remedial stage. ${ }^{41}$ And, furthermore, there is much room for parliamentary analysis of human rights obligations by the JCHR in particular when assessing bills for compatibility, an exercise that is routine and wide-ranging in each session rather than limited to the few cases a year considered by the courts. So the 'normative finality' accepted by Parliament in the cases examined here is in fact a small part of normative scope of the right and balancing exercise associated with it. It is a norm relating to the avoidance of conflict and accepting the court's ultimate interpretive supremacy rather than a reluctance to carry out its own assessments.

More broadly, it is not a widely shared tenet in modern constitutionalism that only legislatures can speak with the authority of a democratic institution. If our view of a contemporary democracy comprises not only respect for rights, but also the practice of rights-based constitutional review, then judicial review can itself claim a non-legislative variety of democratic pedigree. ${ }^{42}$ On that view, which is also held by some prominent deliberative democrats, the question is whether the practice does

\footnotetext{
${ }^{40}$ See below, nn 69 and 70 and accompanying text.

${ }^{41}$ They largely fit, in other words, the model outlined and endorsed in C Sunstein, One Case at a Time: Judicial Minimalism on the Supreme Court (Cambridge MA, Harvard University Press, 2001).

${ }^{42}$ See R Dworkin, 'Introduction: The Moral Reading and the Majoritarian Premise' in his Freedom's Law: The Moral Reading of the American Constitution (Cambridge, MA, Harvard University Press, 1996) 1.
} 
contribute defensibly to outcomes best described as democratic or democracypromoting. ${ }^{43}$ There are features of practice under the HRA that would count favourably in such an analysis.

One such feature is the extent to which courts can assist legislatures to overcome what Rosalind Dixon calls blind spots and burdens of inertia in the legislative process, or what I have elsewhere called an absence of legislative focus on rights issues. ${ }^{44}$ By legislative focus, I mean either that the legislature has not considered the point at all or that the act was adopted at a time when the concept of rights was substantially different from that which the society has presently legally embraced through its constitution or ratification of international instruments. Figure 8.6 demonstrates that approximately 37 per cent of section 4 cases thus far concerned statutes where in my estimation there was an absence of legislative focus.

[Insert Figure 6 around here - absence of legislative focus].

\section{Of the incompatibilities remedied by post-decision legislative response, did the challenged Act manifest legislative focus on the rights-issue?}

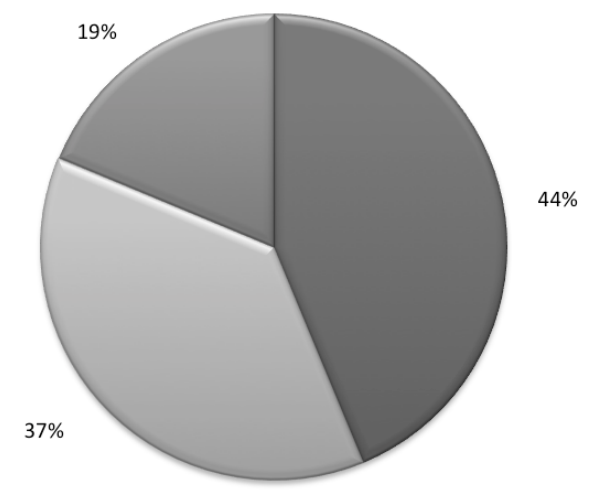

Yes: Roth, Belmarsh, Morris, Wright, Clift, Thompson, R (CN).

$\square$ No: R(H), McR, Blood \& Tarbuck, Bellinger, $R(M)$, Smith $v$ Scott.

Unclear: Wright, Baiai, $\mathrm{R}(\mathrm{D})$.

\footnotetext{
${ }^{43}$ J Habermas, (W Rehg (trans)) Between Facts and Norms (Cambridge, Polity Press, 1996), 280: '[A] rather bold constitutional adjudication is even required in cases that concern the implementation of democratic procedure and the deliberative form of political opinion and will-formation.'

${ }^{44}$ R Dixon, 'Creating Dialogue about Socioeconomic Rights: Strong-Form versus Weak-Form Judicial Review Revisited' (2007) 5 International Journal of Constitutional Law 391, 402ff; J King, Judging Social Rights (Cambridge, Cambridge University Press, 2012) 164-65, 169-73. For an in-depth study of this issue in UK constitutionalism, see A Kavanagh, 'Proportionality and Parliamentary Debates: Exploring Some Forbidden Territory’ (2014) 32 OJLS 443.
} 
Figure 8.5 Of the incompatibilities remedied by post-decision legislative response, did the challenged act manifest legislative focus on the rights issue ${ }^{45}$

Furthermore, Table 8.2 below demonstrates that a substantial majority of successful claimants are from marginalised groups that do not enjoy favourable representation in Parliament. It also shows that most of the remaining claimant groups were, though not in any way particularly vulnerable, still in most cases reasonably discrete and unlikely to register on any political agenda (and hence face what Dixon calls the 'burdens of inertia'). On this view, then, the practice of judicial review has arguably promoted the interests and raised the profile of vulnerable groups, a significant number of whom could not or did not vote at all.

[Insert Table 2 here: please ensure all on one page].

Table 8.2 Claimant groups and section 4 declarations of incompatibility

\begin{tabular}{|c|c|c|c|}
\hline \multicolumn{2}{|c|}{ Marginalised groups } & \multicolumn{2}{|c|}{ Non-marginalised groups } \\
\hline Case & Claimant group & Case & Claimant group \\
\hline$R(H)$ & Mental health patients & Roth & Hauliers, lorry drivers \\
\hline$M c R$ & Homosexual men & Blood and Tarbuck & $\begin{array}{l}\text { Children of deceased } \\
\text { fathers, conceived by } \\
\text { fertility treatment }\end{array}$ \\
\hline Anderson & Prisoners & Wilkinson & Widowers \\
\hline$R(D)$ & Prisoners & Hooper & Widowers \\
\hline Bellinger & Transgender persons & Wright & Care workers \\
\hline
\end{tabular}

${ }^{45}$ This concerns those declarations where the legislative response occurred post-decision, except for Wright, which was nearly simultaneous. In Chester $v$ Secretary of State for Justice [2013] UKSC 63 [136], Lord Sumption rejected the contention that there was no substantive legislative debate supporting the legislative ban on prisoner voting in the UK Parliament supporting the Representation of the People Act 2000. 


\begin{tabular}{|c|c|c|c|}
\hline$R(M)$ & Mental health patients & $\begin{array}{l}R \text { (Royal College of } \\
\text { Nursing) }\end{array}$ & Care workers \\
\hline Belmarsh & Foreign suspected terrorists & & \\
\hline Morris/Gabaj & Poor non-citizens & & \\
\hline Baiai & $\begin{array}{l}\text { Foreigners having non-CoE } \\
\text { marriages }\end{array}$ & & \\
\hline Clift & Prisoners & & \\
\hline Smith v Scott & Prisoners & & \\
\hline Thompson & Convicted sex offenders & & \\
\hline$R(T)$ & $\begin{array}{l}\text { Persons subject to police } \\
\text { cautions }\end{array}$ & & \\
\hline
\end{tabular}

Other features of the practice under the HRA are less favourable from the perspective of deliberative democracy. One such feature is the consistent strategy by the Government of aiming only for 'minimal compliance', one that has provoked 'recurring criticism' by the JCHR. ${ }^{46}$ Another is the time given in Parliament for deliberation. One early concern was whether responses to section 4 declarations might in any way overburden Parliament. Quite to the contrary, the paucity of time spent on floor debates and even in committee proceedings can be quite remarkable, all the more so in view of the delays involved in providing remedies. The response to the Roth case was an interesting example, also noted by Young and Sathanapally. ${ }^{47} \mathrm{In}$ Roth, the Court of Appeal found a penalty regime for hauliers who knowingly or unknowingly transport clandestine entrants into the UK to be an unfair violation of the Article 6 right to a fair trial and disproportionate interference with the right to property under Article 1 of the First Protocol. By way of response, however, the Government introduced the legislative amendment at Report stage in the Commons, and debate on it was severely curtailed by the use of timetabling or 'guillotine'

\footnotetext{
${ }^{46}$ Joint Committee on Human Rights (n 6) [168]-[170].

${ }^{47}$ Young (n 8) 787-88; Sathanapally (n 17) 145-46.
} 
motions, to the dismay of a number of MPs and even peers. ${ }^{48}$ The evidence showed that many parliamentarians wanted much more time, not less, spent on responding to the judgment. Even so, the JCHR praised the resulting Schedule 8 to the Nationality, Immigration and Asylum Act 2002, finding it to be a 'measured and proportionate response to the decision of the Court of Appeal in Roth' ${ }^{49}$

The process leading to the Prevention of Terrorism Act 2005 has been identified as another example of inadequate time for debate. ${ }^{50}$ The Government announced at first reading of the Bill that one of its central purposes was to comply in good faith with the Belmarsh decision, ${ }^{51}$ which found powers permitting indefinite detention of foreign suspected terrorists incompatible with Articles 5 and 14 of the Convention. The Government decided to introduce new legislation rather than prolong the incompatible scheme, which was due to expire within three months of the judgment. As is well known, the Bill's proposed invasions of personal liberty were profound, ${ }^{52}$ and so the first question asked by David Davis MP, the Shadow Home Secretary (Conservative), was: 'What is the immediate emergency that demands that draconian powers against British subjects be rushed through these Houses of Parliament without proper consideration, scrutiny or debate?' ${ }^{53}$ Davis suggested that the Lords' judgment, which he agreed with and supported, ${ }^{54}$ was being used opportunistically to ram through an invasive piece of post-9/11 legislation in short order. The JCHR also protested loudly and clearly:

[T] here can be no justification for including such wide and unprecedented powers of executive detention in legislation which is being rushed through Parliament at a speed which prevents proper scrutiny, in order to be on the statute book in time to deal with

\footnotetext{
${ }^{48}$ See in particular the protest of Baroness Anelay HL Deb, 24 June 2002, vol 636, col 109.

${ }^{49}$ Joint Committee on Human Rights, Immigration, Nationality and Asylum Bill (2001-02, HL 132, HC 961) [110].

${ }^{50}$ Sathanapally's (n 17, 196-204) analysis is particularly thorough.

${ }^{51}$ HC Deb 22 February 2005, vol 431, cols 151-55 (Charles Clarke MP). Such a debate on first reading is exceptional in the legislative process, and ostensibly was due to the high profile of the judgment and the Government's decision to characterise the situation as exceptionally urgent.

${ }^{52}$ The Bill introduced a new scheme of 'control orders', which applied to British nationals as well as foreigners and allowed, among other things, pervasive control of the lives of the controlees through a combination of house arrest, electronic tagging, mobility restrictions and control on communications. The orders, furthermore, could be imposed as a civil measure without the controlee ever seeing the evidence in support of the orders or even being able to communicate with the special advocate who represented him after the advocate had seen closed evidence.

${ }^{53}$ HC Deb 22 February 2005, vol 431, col 156.

${ }^{54}$ ibid (quoting from the judgment in his response to the Home Secretary).
} 
those detained under provisions which are shortly to expire. Legislation passed at such speed should be confined to that which is essential to deal with the problem about to arise ... which means that all of the provisions concerning derogating control orders should be taken out of the Bill, if necessary to be returned to when there is more opportunity for careful parliamentary scrutiny. ${ }^{55}$

Although it is easy (and right) to focus on the parliamentary dismay about the rushed timetable, in actual fact, the legislative response to the Belmarsh decision evidenced by far the most legally and constitutionally sophisticated, highly principled and certainly the most drawn-out parliamentary discussion about the key rights issue identified by the courts under the HRA. The only other bill generating anywhere near the depth, scope and sophistication of response was the post-Bellinger passage of the the Gender Recognition Bill. In both cases, the responses were whole act responses, so we can compare them very crudely by noting the overall volume of discussion to the entire bill in floor debates. If we look to the overall number of words spoken during the floor debates for responses to both decisions, the Commons debate responding to Belmarsh was roughly twice the length of that responding to Bellinger, and the Lords debate was approximately a third longer. ${ }^{56}$ Of course, this comparison does not confirm adequacy of discussion, for the issues were arguably more complex and disagreements far more heated.

If we pan out from these interesting but distinctive examples, a fairly clear theme regarding timing and deliberation emerges from the evidence on the whole. In most cases apart from those mentioned above, there is very little, if any, direct engagement with the rights issues raised in the courts' judgments and almost no engagement with the judicial reasoning itself. In a number of instances, the judgments are not mentioned by name and the issue gets only fleeting mention in the general debates of either House. A more interesting factor, relating more to the legislative process itself, is that the quality of deliberation in Parliament tends to be correlated

\footnotetext{
55 Joint Committee on Human Rights, Prevention of Terrorism Bill: Preliminary Report (2004-05, HL 61, HC 389) [8]. See also Joint Committee on Human Rights, Prevention of Terrorism Bill (2004-05, HL 68, HC 334) para 1.

${ }^{56}$ And both such debates were indeed massive: the Commons Hansard for the Prevention of Terrorism Act 2005 amounts to approximately 150,000 words (according to an MS Word count), whereas the Lords Hansard amounted to approximately 144,000 words. Furthermore, Commons Committee Hansard adds about 75,000 words to that figure, whereas the Lords Committee adds 109,000 words to its own. The Ping Pong stage adds another 125,000 words. In all cases, roll call votes for divisions have been included in the word count, so real figures are somewhat lower.
} 
with the type of response, and specifically whether it is a whole act, remedial order or tacking response. Figure 8.7 gives the present distribution of responses along these lines.

[Insert Figure 7 around here].

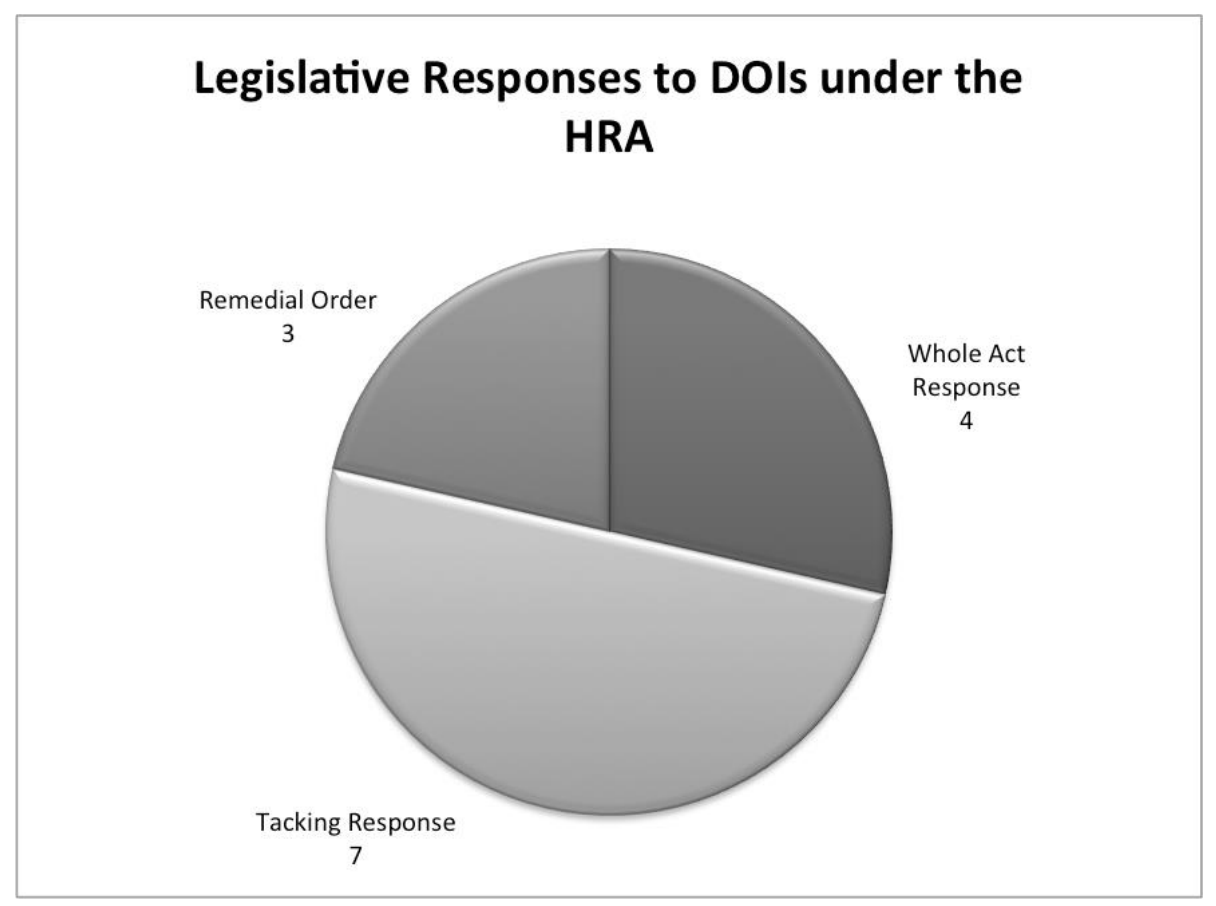

Figure 8.6 Legislative responses to DOIs under the HRA

Notwithstanding a clear preference for tacking responses, the evidence suggests that there is much clearer engagement with the rights issue and remedial options in cases of both whole act responses and, though to a much lesser extent, parliamentary scrutiny of remedial orders. There are a few reasons for this. The first is that the rights issue is likely to figure more prominently among the key issues during the second reading of the bill, where its key principles are debated and views of the House can not only be formed but also fed into the subsequent amendments at committee stage before executive views become ossified. Another is that tacking amendments are often inserted into extremely important and wide-ranging bills that will affect millions of people. ${ }^{57}$ MPs and peers are thus likely to face issue

\footnotetext{
${ }^{57}$ Some examples include the Criminal Justice Act 2003 (response to Anderson); the Mental Health Act 2007 (much delayed response to $R(M)$ ); the Housing and Regeneration Act 2008 (delayed response to Morris and Gabaj); and the Sexual Offences Act 2003 (response to McR).
} 
exhaustion, and compatibility issues will be subordinated to the more important battles. Furthermore, tacking responses tend to get introduced late in the legislative process and sometimes quite late in the day (or evening), compounding issue exhaustion with physical exhaustion.

The debates concerning remedial order responses, on the other hand, are focused precisely on the rights issue, and the dossier available to parliamentarians will make the JCHR reports central to the issue before them, ${ }^{58}$ and the JCHR has been no less vigilant in its review of proposed remedial orders (as well as of the use of the remedial order procedure). The possible flaw with them, however, is that since they are executive orders approved by resolution rather than primary legislation, they may enjoy an even lower profile in Parliament than have some of the other amendments. For instance, the debate in the Lords concerning the remedial order following the Thompson case (concerning the rights of sex offenders to request their removal from the Sex Offenders Register) reads very well in Hansard. It is focused, careful and engaged with material points raised in the JCHR report. What Hansard did not report, however, was that there were fewer than 10 peers in the room during the debate and more than one was evidently not paying attention to the discussion. ${ }^{59}$ Indeed, a debate an hour earlier on a motion regarding the welfare and transportation of horses in the EU was much more lively and well attended. Even so, the JCHR has urged the Government to make more frequent use of remedial orders to 'remedy incompatibilities more swiftly'. ${ }^{60}$ And were one asked to rank the quality of deliberation and scrutiny in types of parliamentary responses, the clear order appears to be whole acts, followed by remedial orders, followed by tacking responses.

\section{A Constitutional Convention of Response?}

Albert Venn Dicey considered that the conventions of the constitution 'consist of maxims or practices which, though they regulate the ordinary conduct of the Crown,

\footnotetext{
${ }^{58}$ Remedial orders followed $R(H)$, Baiai and Thompson, the details for which are available in the Ministry of Justice's Responding to Human Rights Judgments (2012, Cm 8432) Annex A.

${ }^{59}$ These are based on the author's observations from the gallery during the debate, which is reported in HL Deb 5 July 2012, vol 436, cols 876ff. There are (remarkably) no official attendance records.

${ }^{60}$ Joint Committee on Human Rights (n 6) para 22.
} 
of Ministers, and of other persons under the constitution, are not in strictness laws at all' ${ }^{61}$ The hallmark of a constitutional convention in this tradition is that it is regarded as constitutionally binding, but not legally binding. Some authors, Aileen Kavanagh prominent among them, have speculated there may be an emerging constitutional convention in favour of legislative amendment following a section 4 declaration. ${ }^{62}$ This section presents evidence that supports that view, though it is not conclusive.

In an influential ${ }^{63}$ analysis, Ivor Jennings identified three key questions in any inquiry about the existence of a constitutional convention: 'First, what are the precedents; secondly, did the actors in the precedents believe that they were bound by a rule; and thirdly, is there a reason for the rule? ${ }^{64}$ Starting with the first of these for our present subject, the precedents suggest an almost uniform practice of legislative amendment by way of response. The arguable exception has been the Smith $v$ Scott decision on prisoners' rights to vote (which accepts and applies the decision of the European Court of Human Rights in Hirst), yet there too, as discussed above, a response is awaited. ${ }^{65}$ At any rate, this one instance of either extreme delay or noncompliance is not conclusive. Some commentators do not believe that complete uniformity of action is required to establish a constitutional convention, ${ }^{66}$ and in international law it is not necessary that a practice manifest 'absolutely rigorous conformity with the rule' in order to determine the existence of legally binding international custom. ${ }^{67}$ And, as previously noted, the distinctive aspect of that case is that anger has been directed at Strasbourg rather than at UK courts, the latter tending (with some variation) to agree with the Government that the issue is a matter for Parliament. ${ }^{68}$

\footnotetext{
${ }^{61} \mathrm{AV}$ Dicey, Introduction to the Study of the Law of the Constitution (10th edn, London, Macmillan, 1959) $23-24$.

${ }^{62}$ Kavanagh (n 17) 289. See also 488.

${ }^{63} \mathrm{See}$, eg, Reference re Questions Concerning Amendment of Constitution of Canada [1981] 1 SCR 753, 888 (the 'Patriation Reference').

${ }^{64}$ I Jennings, The Law and the Constitution (5th edn, London, University of London Press, 1959) 136. See also J Jaconelli, 'Do Constitutional Conventions Bind?' (1999) 64 CLJ 149; N Barber, 'Laws and Constitutional Conventions' [2009] LQR 194.

${ }^{65}$ See White (n 10).

${ }^{66}$ Jaconelli (n 64) 153, but see also 165-66.

${ }^{67}$ Military and Paramilitary Activities in and against Nicaragua Case (Nicaragua v United States of America) (Merits) [1986] ICJ Rep 14 [186].

${ }^{68}$ This was the approach taken in the judgment of Laws LJ in Chester $v$ Secretary of State for Justice
} 
Passing over the second question momentarily, we can consider the third, which is whether there is a reason for the rule. Different answers are plausible. The sceptical view, which we may associate with Francesca Klug and Danny Nicol, ${ }^{69}$ would maintain that it was precisely both the legal and policy aim of the HRA to reserve legal and political sovereignty for the UK Parliament, as supplemented by the well-informed activity of the JCHR. Gardbaum also argues that a legislative response should not follow automatically, but rather that Parliament should have the political discretion to reasonably disagree with the court's assessment. ${ }^{70}$ The more supportive view of a constitutional convention could offer the following reasons for the rule: to not do so would: (a) likely put the UK in breach of its binding international obligations; (b) disrupt the scheme of the HRA, which seeks to give real rather than illusory remedies in UK courts for violations of Convention rights; and (c) undermine the constitutional position of the judiciary and thus strain relations of comity between it and the other branches of government. And by way of rebuttal of the sceptical view, critics could point to the widely held view that the HRA was intended to function in a scheme that would generate considerable if not overwhelming political pressure to amend the laws to ensure conformity. On this view, the parliamentary sovereigntist's proper mode of disagreement would be to repeal or amend the HRA, or take an exceptional legislative stand on particular issues when they arise.

If we turn to the second of Jennings' questions - whether the actors felt bound to obey-then we can see that parliamentary views have been uneven, but when matters have come to a head, most have sided more with the view that there is some sort of obligation. Although this is not the place for an exhaustive survey, some

[2010] EWCA Civ 1439, which ruled not only that a second declaration of incompatibility was inappropriate, but also, at [32]-[35], that the question of prisoner enfranchisement was in principle not a matter suitable for resolution in UK courts. In the Supreme Court decision on this case ([2013] UKSC 63), the leading judgment of Lord Mance concentrated almost entirely on the obligation to give effect to Strasbourg jurisprudence on the topic and touched very briefly upon the genuine rights issue at issue: compare [35] with the remainder of his judgment. Lady Hale and Lord Clarke did discuss the substantive issues briefly ([86]-[98]; [109]-[111]), while Lord Sumption discussed the substantive matter at the greatest length and concluded at [137] that he would not have found UK arrangements incompatible with the Convention absent the clear view of the Strasbourg Court on the matter. See also Pearson and Feal-Martinez (n 14) for similar statements.

${ }^{69}$ F Klug, 'Judicial Deference under the Human Rights Act 1998' [2003] European Human Rights Law Review 125, 131; D Nicol, 'Law and Politics after the Human Rights Act' [2006] Public Law 722, 744.

${ }^{70}$ Gardbaum (n 15) 27, 36, 123, 201-02. For my critique of this proposal, see J King, 'Rights and the Rule of Law in Third Way Constitutionalism' (2014) 30 Constitutional Commentary 101. 
examples corroborate this view. The first can be found in a pertinent statement in the White Paper setting out the case for the Human Rights Bill: '2.10 A declaration that legislation is incompatible with the Convention rights will not of itself have the effect of changing the law, which will continue to apply. But it will almost certainly prompt the Government and Parliament to change the law. ${ }^{71}$ This is consistent with views later stated in Parliament during some responses to declarations of incompatibility. For example, after the decision in $A$ and others $v$ Secretary of State for the Home Department, the then Home Secretary, Charles Clarke, engaged in the following exchange during the second reading for what became the Prevention of Terrorism Act 2005:

Mr. Clarke (Home Secretary): The third motivating principle [for the bill] is the need to meet the Law Lords' judgment. In general, I do not regard it as a successful and positive state of affairs when the senior judiciary of this country, the Law Lords, and the Executive are in rather different places, and certainly not in terms of measures of this type. Their criticism of the regime in place was that it was disproportionate in character and discriminatory, and we should take that criticism extremely seriously. The measures that I am putting to the House in the Bill would address that question directly.

Mr. Cash (Con): ... It is not a question of whether or not he is complying with the Law Lords' judgment. The problem arises because the Government have got themselves into a complete mess with regard to the human rights legislation. Surely the point is simply that, to ensure that the House can legislate on its own terms, it must legislate notwithstanding the Human Rights Act 1998, and then he is in the clear. Does he not see that?

Mr. Clarke: I do not accept any of that. I simply do not accept the argument. I do not think that it is correct. What I do think is that when the Law Lords of this country make a set of criticisms about the way that we are operating that is well founded, by a vote of eight to one, it is incumbent on the Government - and, I would argue, on Parliament - to respond to that and decide how to deal with it. ${ }^{72}$

In an earlier part of the debate, as well, Mr Clarke observed that: 'If the Law Lords say that we have discriminatory and disproportionate legislation, I believe that there is an obligation on the whole House, not simply on the Government, to address that, and that is what we are doing. ${ }^{73}$

\footnotetext{
${ }^{71}$ Rights Brought Home: The Human Rights Bill 1997 (Cm 3782, 1997) para 2.10.

${ }^{72}$ HC Deb, 23 February 2005, vol 431, cols 345-46.

${ }^{73}$ HC Deb 22 February 2005, vol 431, col 158.
} 
In almost all legislative responses, there have been no direct calls by frontbenchers to disregard a declaration of incompatibility by UK courts. Indeed, one must look with diligence to find any reference to the judicial decision in most parliamentary debates, and in a few cases there is none at all. There have been occasional references to the 'non-binding' nature of the declarations, however. For instance, the JCHR in its report in the 2002-03 session commented that, unlike after an adverse decision of the European Court of Human Rights, the Government is not 'obliged' to respond to a declaration of incompatibility. ${ }^{74}$ And while in the response to the Roth decision of the Court of Appeal, the Home Secretary, David Blunkett, at one point said 'We must also take account of the Roth judgment ... and we shall table an amendment', another minister (Rosie Winterton) later tabled the amendment itself declaring that at least part of it 'addresses a non-binding concern of the Court of Appeal in Roth' ${ }^{75}$ However, both these statements appear to refer to a legal notion of bindingness rather than anything material to a constitutional convention.

Until quite recently, and apart from the distinctive issue of prisoner voting that I have addressed above, nearly all cases have not been about whether to amend the legislation, but rather how. However, the response to the Thompson case broke new ground in ways that both support and detract from the view that there is a constitutional convention of response by amendment. In Thompson, the Supreme Court held incompatible a legislative scheme that prevented convicted sex offenders from having any possibility of having their names removed from the Sex Offenders Register. Both the Prime Minister, David Cameron, ${ }^{76}$ and the Home Secretary, Theresa May, ${ }^{77}$ declared themselves 'appalled' by the Court's decision, a sentiment echoed by the Labour Shadow Home Secretary, Yvette Cooper, when the matter came before Parliament. ${ }^{78}$ Indeed, even Jack Straw, a former Labour Lord Chancellor and Secretary of State for Justice, had the following to say in support of his political adversary:

\footnotetext{
${ }^{74}$ Joint Committee on Human Rights, Draft Gender Recognition Bill (Nineteenth Report) (2002-03, HL Paper 188-I, HC 1276-I) para 17.

${ }^{75}$ HC Deb 12 July 2002, vol 386, col 928.

${ }^{76}$ R Ford, 'Sex Register Ruling Provokes an Outrage' The Times (London, 17 February 2011) 5.

${ }^{77}$ HC Deb 16 February 2011, vol 523, col 959.

${ }^{78}$ HC Deb 16 February 2011, vol 523, cols 959-69.
} 
I support the Home Secretary's views on the merits of the existing sex offenders register and her concern about the Court's decision, but will she confirm that under section 4 of the Human Rights Act 1998 there is absolutely no obligation on her or the House to change the law one bit? All the Court did was to issue a declaration of incompatibility and section 4 makes it absolutely clear that any decision following that is a matter for the sovereign Parliament. It would be entirely lawful for the House and her to say that the existing regime will continue without any amendment. ${ }^{79}$

This statement flatly contradicts the idea of a constitutional convention, from a senior parliamentarian. By way of reply, the Home Secretary noted his statement, but continued with her overarching message that 'we are appalled by the decision ... but we do have to make a change. We will do so in the most minimal way possible' ${ }^{80}$ Furthermore, the Government delivered a mixed message in its subsequent parliamentary introduction of the remedial order. It arose for consideration first in a delegated legislation committee, where the Parliamentary Under-Secretary of State, Lynne Featherstone, a Liberal Democrat member of the Coalition Government, introduced and discussed the remedial order. Her view of the Court's decision was more upbeat:

We clearly believe that it was a correct judgment and, as the Government, we comply with Supreme Court judgments ... We do not believe that a public review is neededthe ruling was quite clear and unequivocal, and we have responded. ${ }^{81}$

The language of compliance here, also found in other relevant portions of Hansard, implies the existence of an obligation. Furthermore, when the remedial order was introduced in the Lords a month later by Baroness Stowell of Beeston, a Conservative peer, she stated the following:

Our constitutional arrangements are such that when the highest court of the land identifies an incompatibility with the European Convention on Human Rights, the Government of the day, whoever is in power, take remedial action. This is for various reasons, not the least of which is to ensure that the Government are not left vulnerable to further legal proceedings, potentially involving millions of pounds of taxpayers' money ... The Government were disappointed with the UK Supreme Court's ruling, but we take our responsibility to uphold the law seriously, and that includes human rights law. ${ }^{82}$

This is presently where matters lie. It is not possible to conclude that there is a constitutional convention that there should be a legislative amendment as a reply to a

\footnotetext{
${ }^{79}$ HC Deb 16 February 2011, vol 523, col 963.

${ }^{80}$ HC Deb 16 February 2011, vol 523, col 961.

${ }^{81}$ HC Deb 19 June 2012, vol 546, col 10 (Eight Delegated Legislation Committee, Draft Sexual Offences Act 2003 (Notification Requirements) (England and Wales) Regulations 2012).

${ }^{82}$ HL Deb 5 July 2012, vol 738, cols 875, 886.
} 
declaration of incompatibility; however, evidence is mounting that one is perceived by the Government and some legislators to exist. Of course, conventions can change and there are furthermore the deeper questions of whether any purported convention would require legislative amendment or only good faith engagement with the issue, and whether the convention only applies to declarations of incompatibility made by the Supreme Court or to any final declaration of incompatibility decision (recalling that 14 out of 20 final declarations have issued from lower courts). Proper discussion of such matters must be addressed on another day.

\section{Conclusion}

The HRA is a key constitutional statute in the UK and has created a new and exciting period in law and politics. This chapter has explored the feature of that system that is most novel in comparative perspective, namely, the ability to declare primary legislation incompatible with human rights without legally affecting its validity or continuing operation. I sought to elaborate upon some of the distinctive aspects of the UK system, drawing a sometimes sharper contrast between it and foreign systems than is sometimes noticed.

A set of such contrasts was examined in the discussion of the distinctiveness of the HRA. I found there that delay, when combined with the absence of retroactive relief, damages or restitution, interim relief and the constitutional infirmity of the HRA itself, amounted to significant differences between the HRA and other systems, including that of Canada. In the subsequent section, I concluded that the declaratory nature of the power under the HRA did not appear to prompt courts to be any more assertive in their findings of non-compliance with the Convention. By international comparison, they tend rather to be on the cautious side in terms of numbers of declarations issued and also with the intrusiveness of the individual judgments they have given. The portrait suggests a non-activist judiciary, though nothing there supports the view that they have not done their job under the HRA. These are not akin to statistics regarding convictions for rape, where the numbers alone give cause to shudder. 
As to the question of whether the experience under the HRA has promoted deliberative democracy, I noted that there is little evidence that the Government and Parliament feel dominated by judges under the HRA, and section 4 declarations are not a significant issue for them. The evidence instead supports a view of collaboration and divided responsibilities, with courts adjudicating cases and setting out findings on narrow issues, while the Government and Parliament work from these conclusions to refashion policy accordingly. Where there has been serious tension (eg, after the Anderson case and the Thompson case), the Government fought back by presenting to Parliament a policy that was different in only small ways from the original policy. Indeed, the responses to Anderson and Belmarsh may well have been regressive if we consider the matter in utilitarian terms.

At the same time, most of the cases raised issues that Parliament had not considered in great depth (where there was an absence of legislative focus) and about which it often had no strong feelings. Since most cases were taken by marginalised groups, there is evidence of enhanced deliberative input, in the sense of ensuring that the needs of people who have less voice are properly taken into account in public decision-making. I further found that whole act responses and remedial orders were better than tacking responses, which make scant room for proper scrutiny of the implications of remedial measures. I lastly presented evidence that tends to support the view, though is ultimately inconclusive, that there exists a constitutional convention of responding to section 4 declarations of incompatibility. The Government and many parliamentarians do appear to feel obligated to respond to a section 4 declaration, at least so long as the HRA is in force. This appears to be proper constitutional policy, though there is room for considerable further analysis of this point.

One final point has not yet been given sufficient emphasis: the quality of much of these parliamentary debates is extremely impressive and not just (or even primarily) in the Lords. The popular picture of parliamentarians as crude rent-seekers is belied by the record here. The following comment by Mr Christopher Leslie (Labour), concluding the debate prior to the vote on the second reading of the Gender Recognition Bill, is more characteristic of the UK Parliament: 
I believe that the test of a civilised society is its approach to minorities and the respect that we have for their rights. Transsexual people face obstacles and legal problems on a day-to-day basis, quite unnecessarily. They have human rights that need defending, and freedoms that deserve respect. The Bill will right a wrong that currently exists, and I commend it to the House. ${ }^{83}$

The vote that followed immediately was 336 in favour, with 26 against. While there is important room for improvement, the record tends on the whole to demonstrate in no small way the virtues of a parliament that takes rights seriously, working for the most part in constitutional harmony with its colleagues on the bench.

${ }^{83}$ HC Deb 23 February 2004, vol 418, col 105. 